\title{
NEW RESEARCH PROBLEMS IN THE THEORY OF PUBLIC ECONOMIC LAW - SUMMARY REPORT FROM THE CONFERENCE (WROCLAW, 14-15 JUNE 2010)
}

\author{
JAN GOLA* \\ KAMIL WIECCKOWSKI**
}

An official conference entitled 'New research problems in the theory of public economic law (with regard to self-government)' took place on 14 and 15 June 2010. It was organized by staff and $\mathrm{PhD}$ students of the Department of Public Economic Law at the University of Wroclaw and the Department of Public Economic Law at the Adam Mickiewicz University of Poznań, and held under the honorable patronage of the Marshal of Lower Silesia, Maciej Lapiński, and the Dean of the Faculty of Law, Administration and Economics, Prof. Włodzimierz Gromski.

Over the two days, the conference attracted delegates representing the Department of Public Economic Law at the University of Poznań: Prof. Teresa Rabska, Prof. Bożena Popowska, Dr Katarzyna Kokocińska, Dr Piotr Lissoń, Dr Anna Trela, Dr Michał Strzelbicki and Mateusz Chołodecki. The Department of Public Economic Law at the University of Wroclaw was represented by: Prof. Leon Kieres, Prof. Karol Kiczka, Dr hab. Tadeusz Kocowski, Dr Andrzej Borkowski, Dr Maciej Guziński, Dr Krzysztof Horubski, Oskar Filipowski, Izabela Gancarz, Jan Gola, Anna Goździńska, Grzegorz Klich, Marcin Pawłowski, Tomasz Sobel, Eugeniusz Szydłowski, Ewa Tokarek, Kamil Więckowski and Krzysztof Woźniak.

The session was opened by the dean of the Faculty of Law, Administration and Economics, Prof. Włodzimierz Gromski, and the director of the Institute of Administrative Sciences, Prof. Jan Boć, who made reference to the long-standing collaboration of these two research centers $^{1}$. Thereafter Prof. Leon Kieres introduced the purpose of the

DOI: $10.2478 /$ wrlae-2013-0044

* PhD candidate; LLM; Department of Public Business Law, University of Wroclaw.

j.gola@prawo.uni.wroc.pl

** PhD candidate; LLM; Department of Public Business Law, University of Wroclaw.

kwieckowski@prawo.uni.wroc.pl

1 Bożena Popowska, 'Dedykacja i wspomnienia' in Bożena Popowska (ed), Funkcje współczesnej administracji gospodarczej. Księga dedykowana Profesor Teresie Rabskiej (Wydawnictwo Poznańskie 2006) 5; Karol Kiczka, 'Sprawozdanie z konferencji naukowej pracowników Katedry Publicznego Prawa Gospodarczego UAM w Poznaniu oraz Zakładu 
meeting, interest in new research problems in the theory of public economic law, drawing particular attention to the self-government issue and emphasizing the tradition of joint meetings of almost 30 years, initiated by Prof. Teresa Rabska and the late Prof. Adam Chełmoński, who organized the first conferences and marked out the subjects for further scientific discussions and joint research.

On the first day of the conference the chair was taken by Prof. Leon Kieres. During the meeting issues of the relationship between public economic law and the theory of law were under discussion. The participants - inspired by the article of Prof. Teresa Rabska - deliberated the task of a legal norm which exists (a task of standards) in public economic law. They emphasized (indicated) that theoretical construction of a legal norm describing tasks (a task legal norm) has a significant impact on this branch of law. Prof. Teresa Rabska remarked on the necessity of ordering terms used in public economic law which are determined by both theoretical and practical reasons.

In the subsequent (following) part of the meeting Dr Katarzyna Kokocińska presented a paper, 'Municipality as an entity of development policy'. Reflections mainly concerned the act on principles of development policy. The speaker touched on the issue of the scope of the tasks of decentralization, defined by the legislature as a development policy. The coherence of this policy is based on the interrelated activities of those who are engaged in it, namely the Council of Ministers, regional government and self-government, while the determinant of that above mentioned scope is the fundamental principal of subsidiarity.

Thereafter Dr Anna Trela presented a paper entitled 'Admissibility of economic activities of local government units outside the realm of public service in the light of proposed changes to the law on municipal management'. Based on an analysis of the proposed changes in the said act, the author reported a call for general and universal principles for form and the joining of local government with companies outside the sphere of public utilities. These should focus mainly on public purpose and be in coherence with the entire legal system, governing the position and functioning of local government.

In his speech 'Tasks of municipalities in the local market for alcohol and proposed amendments to the Act on Upbringing in Sobriety and Counteraction (Prevention) of Alcoholism' Dr Michał Strzelbicki characterized amendments to the above mentioned act. The author analyzed the changes in the law aimed at depriving the municipality of the possibility of issuing resolutions on the maximum number and location of alcohol outlets.

Dr Piotr Lisson in turn discussed the issue of 'Policy as an instrument of control in the sphere of energy law'. He carefully examined the EU and national legislation in this area, indicating its evolution at different stages of EU integration.

Thereafter in a speech, 'Ownership unbundling in the context of the EU protection of property', Marcin Pawłowski considered in detail the institution of ownership unbundling. On the basis of both EU and national

Prawa Administracyjnego Gospodarczego Uniwersytetu Wrocławskiego, Poznań, 9-10 czerwca 2008 r.' (2009) 80 Przegląd Prawa i Administracji 205. 
legislation the author pointed out the differences between ownership unbundling and other forms of separation. This difference is linked to the degree of intensity of the interference in the ownership of the company.

The second day of deliberations was chaired by Prof. Bożena Popowska. As the first lecture, Anna Goździńska presented the subject of 'The municipality and the local market for municipal waste collection services'. Reflections made by the author were related to aspects of the local market for collection of municipal waste from property owners, important from the perspective of municipal solid waste management. The speaker pointed out that there are neither legal nor any other reasons why the local service market in the collection of municipal waste would not be a competitive market, and entrepreneurs acting on it would not have to compete with each other, on both price and other terms of service.

Grzegorz Klich in turn presented the paper 'Trends in the system of legal protection in public procurement law'. The author analyzed regulation of legal protection from interwar legislation through to recent laws amending public procurement law, to which he devoted the most attention. He advocated the implementation of a rational and effective system of legal protection ensuring prompt and effective adjudication of disputes and guaranteeing the possibility of controlling the widest possible group.

Then Oskar Filipowski presented a lecture entitled 'Prohibited clauses in collective water supply and waste disposal collection'. The author described the important issues related to the activities of local government units in the area of government service. Particular attention was paid to protecting the collective interests of consumers on the market for collective water supply and indicating that in the near future changes are expected in the approach of the competition authority, with more of its proceedings brought for violation of the collective interests of consumers on the market for collective water supply and collective sewage disposal, instead of proceedings for abuse of dominance.

In the paper 'Notes about business and entrepreneurs' Tomasz Sobel aimed to present a different perspective on the fundamental issue of public economic law and attempted to determine whether the Polish constitutional principal of freedom of establishment is convergent with EU legislation.

Dr Krzysztof Horubski in turn took the theme 'Participation of municipalities in a company conducting activities in the sphere of professional sport'. This author of an extensive analysis of the legislation paid particular attention to the controversies that arise around the question of community participation in companies operating in the sphere of professional sport. He considered also the concept of 'importance to the development community', which is a prerequisite for community participation when joining or creating municipality sports in the light of the law on municipal management.

The paper entitled 'Prohibition of business activity by persons performing public functions and dilemmas concerning the concept of economic activity', which closed the meeting, was presented by Jan Gola. The author described the institution of material incompatibility in relation to the prohibition of business activity by persons holding public functions. 
This regulation was expressed in the regulations of anti-corruption law (law on the reduction of business activity by persons holding public functions).

In a speech closing the session Prof. Bożena Popowska thanked the guests for their participation in the conference, noting that she considered it fruitful. One further result of the conference is a book published under the title New research problems in the theory of public economic law (including self-government $)^{2}$.

${ }^{2}$ Leon Kieres (ed), Nowe problemy badawcze w teorii publicznego prawa gospodarczego ( $z$ uwzględnieniem samorzadu terytorialnego) (Kolonia Sp. z o.o. 2010). 